\title{
ANALISIS FINANSIAL POLA TANAM AGROFORESTRI DI DESA PESAWARAN INDAH KECAMATAN PADANG CERMIN KABUPATEN PESAWARAN PROVINSI LAMPUNG
}

\section{(FINANCIAL ANALYSIS OF AGROFORESTRI CROPPING PATTERNS IN PESAWARAN INDAH VILLAGE PADANG CERMIN SUB DISTRICT PESAWARAN DISTRICT LAMPUNG)}

\author{
Nurpine Nadeak, Rommy Qurniati, dan Wahyu Hidayat \\ Jurusan Kehutanan Fakultas Pertanian Universitas Lampung \\ Jl. Pof. Dr. Sumantri Brojonegoro No. 1 Bandar Lampung, 35145 \\ E-mail : nurpinenadeak@gmail.com
}

\begin{abstract}
ABSTRAK
Agroforestri dalam Bahasa Indonesia, dikenal dengan istilah wanatani, arti sederhananya adalah menanam pepohonan di lahan pertanian. Pengelolaan lahan dengan sistem agroforestri yang berkelanjutan diharapkan akan mampu meningkatkan produktivitas lahan secara keseluruhan. Untuk itu perlu dilakukan analisis finansial terhadap pola tanam agroforestri pada beberapa jenis tanaman yang dominan di lahan agroforestri petani. Penelitian yang dilaksanakan di Desa Pesawaran Indah Kecamatan Padang Cermin Kabupaten Pesawaran Provinsi Lampung pada bulan Maret-Mei 2012 bertujuan untuk mengetahui pola tanam agroforestri yang paling menguntungkan berdasarkan analisis finansialnya. Pengambilan sampel dilakukan dengan menggunakan teknik purposive sampling. Analisis finansial pola tanam agroforestri menggunakan metode NPV, BCR dan IRR dengan umur kelayakan usaha 20 tahun dan tingkat suku bunga 12\%. Hasil penelitian menunjukkan bahwa terdapat 9 pola tanam agroforestri yang diterapkan petani dan berdasarkan hasil analisis dapat dikatakan. layak secara finansial. Diantara kesembilan pola tanam tersebut pola VI yang merupakan kombinasi Kakao, Kelapa dan Pisang memiliki keuntungan yang paling tinggi dengan nilai NPV sebesar Rp 71.392.802,34,-, BCR sebesar 7,39 dan IRR sebesar 96\%.
\end{abstract}

Kata kunci : agroforestri, analisis finansial, pola tanam

\section{ABSTRACT}

Agroforestry in Indonesian language simply means as planting trees on agricultural land. Land's management with sustainable agroforestry systems expected to be able improve field productivity. It has needed to do financial analysis for agroforestry cropping patterns. It based on some of dominant plant species in agroforestry cropping patterns. This study conducted in the Pesawaran Indah Village of Padang Cermin Subdistrict on Pesawaran District in March-May 2012. The study aims to determine a profitable agroforestry cropping patterns based on financial analysis. Sampling used by purposive sampling technique. Financial analysis of agroforestry cropping pattern used the NPV, BCR and IRR with feasibility age of 20 years and an interest rate of 12\%. The results showed that there are 9 agroforestry cropping patterns applied. Analysis showed that agroforestry cropping patterns is financially viable to be applied. Among 9 cropping pattern, pattern VI which is combination of Cocoa, Coconut and Banana has the highest profit with NPV is Rp 71.392.802,34,-, BCR of 7,39 and an IRR of $96 \%$.

Key words : agroforestry, financial analysis, pattern 


\section{PENDAHULUAN}

Sistem agroforestri telah banyak diterapkan oleh petani di berbagai tempat di Indonesia. Salah satu daerah yang menerapkan sistem agroforestri adalah Desa Pesawaran Indah Kecamatan Padang Cermin Kabupaten Pesawaran. Sistem agroforestri yang diterapkan di Desa tersebut umumnya merupakan kombinasi tanaman berkayu (pohon) dengan tanaman bukan kayu (pertanian dan perkebunan). 85\% masyarakat yang tinggal di Desa Pesawaran Indah hidup sebagai petani dan mengelola lahannya dengan sistem agroforestri. Jenis-jenis pohon penghasil kayu yang banyak ditanam di lahan agroforestri adalah Cempaka, Bayur, Jati, Sengon, Medang dan Waru sedangkan jenis-jenis tanaman pertanian dan MPTS (Multi Purpose Tree Species) yang banyak ditanam meliputi Kakao, Pisang, Kopi, Kelapa, Pala, Cengkeh, Durian dan Petai. Diantara berbagai jenis tanaman yang ditanam masyarakat tersebut, jenis tanaman Kakao yang paling mendominasi sebesar $60 \%$.

Secara keseluruhan lahan agroforestri yang dikelola di Desa Pesawaran Indah merupakan tanah milik masyarakat. $90 \%$ petani menggantungkan hidupnya dari hasil agroforestri tersebut. Untuk itu perlu dilakukan analisis finansial terhadap pola tanam agroforestri berdasarkan beberapa jenis tanaman yang dominan di lahan agroforestri untuk mengetahui pola tanam yang lebih menguntungkan secara finansial untuk diterapkan petani. Penelitian ini bertujuan untuk mengetahui pola tanam agroforestri yang nilai finansialnya lebih tinggi di Desa Pesawaran Indah Kecamatan Padang Cermin Kabupaten Pesawaran berdasarkan analisis finansial.

\section{METODE PENELITIAN}

Penelitian dilaksanakan di Desa Pesawaran Indah Kecamatan Padang Cermin Kabupaten Pesawaran Provinsi Lampung pada bulan Maret-Mei 2012.

Objek penelitian yaitu petani yang menerapkan sistem agroforestri di Desa Pesawaran Indah. Alat yang digunakan dalam penelitian ini meliputi panduan wawancara atau kuesioner, alat tulis, kamera, kalkulator, komputer dan alat bantu lainnya.

Jenis data yang dikumpulkan yaitu:

1. Data primer meliputi data mengenai kondisi lahan, pola tanam agroforestri yang diterapkan, hasil agroforestri, penerimaan dan biaya produksi pada penerapan pola tanam agroforestri.

2. Data sekunder meliputi data monografi Desa Pesawaran Indah dan literatur lainnya yang telah tersedia dalam bentuk catatan tertulis dan diperoleh secara tidak langsung.

Metode pengumpulan data berupa:

1. Teknik observasi: pengamatan secara langsung oleh peneliti untuk mengambil data-data berdasarkan kondisi tertentu sesuai dengan maksud penelitian.

2. Teknik wawancara: data dikumpulkan melalui tanya jawab yang dilakukan langsung terhadap responden dengan menggunakan kuesioner.

3. Studi pustaka: pengumpulan data dilakukan dengan mengumpulkan berbagai data penunjang penelitian yang diperoleh dari studi literatur dan instansi-instansi terkait.

Responden dalam penelitian ini adalah petani yang mengelola lahan agroforestri di Desa Pesawaran Indah. Pengambilan responden dalam penelitian ini menggunakan teknik purposive sampling yaitu pengambilan sampel responden secara sengaja (tidak acak) yang disesuaikan dengan tujuan penelitian (Arief, 2007). Dengan pertimbangan bahwa sampel memenuhi kriteria yang diperlukan dalam penelitian yaitu responden menerapkan pola tanam agroforestri yang digunakan dalam penelitian. Penentuan sampel menggunakan rumus Slovin dalam Umar (2000) sebagai berikut: 
$\mathrm{n}=\frac{\mathrm{N}}{1+\mathrm{N}(\mathrm{e})^{2}}$

Keterangan:

$\mathrm{N}=$ jumlah kepala keluarga $(\mathrm{KK})$ di lokasi penelitian

$\mathrm{n}=$ jumlah sampel yang diambil dalam penelitian

$\mathrm{e}=$ batas eror $15 \%$

1 = bilangan konstan

$\mathrm{n}=\frac{900}{1+900(15 \%)^{2}}=42$ responden $(\mathrm{KK})$.

Berdasarkan rumus di atas maka jumlah responden dalam penelitian ini sebanyak 42 responden atau KK.

Analisis finansial dilakukan dengan menghitung Net Present Value (NPV), Benefit Cost Ratio (BCR), Internal Rate of Return (IRR). Rumus yang digunakan adalah sebagai berikut (Suharjito, dkk, 2003):

1. Net Present Value (NPV)

Net Present Value merupakan selisih antara penerimaan dengan biaya. Penerapan pola tanam menguntungkan apabila NPV $>0$, sebaliknya jika NPV $<0$ berarti tidak menguntungkan.

$\mathbf{N P V}=$ PVpenerimaan $-\mathrm{PV}$ pengeluaran

$=\sum_{t=1}^{t=n} \frac{\mathrm{Bt}}{(1+\mathrm{i})^{\mathrm{t}}}-\sum_{t=1}^{t=n} \frac{\mathrm{Ct}}{(1+\mathrm{i})^{\mathrm{t}}}=\quad \sum_{t=1}^{t=n} \frac{\mathrm{Bt}-\mathrm{Ct}}{(1+\mathrm{i})^{\mathrm{t}}}$

Keterangan:

$\mathrm{NPV}=$ nilai bersih sekarang $(\mathrm{Rp})$

$\mathrm{PV}=$ nilai sekarang $(\mathrm{Rp})$

$\mathrm{Bt}=$ manfaat yang diperoleh setiap tahun (Rp)

$\mathrm{Ct} \quad=$ biaya yang dikeluarkan setiap tahun $(\mathrm{Rp})$

$\mathrm{i} \quad=$ suku bunga $(12 \%)$

$\mathrm{t} \quad=$ periode waktu (20 tahun)

2. Benefit Cost Ratio (BCR)

Penerapan pola tanam agroforestri dapat dikatakan menguntungkan apabila nilai Net B/C > 1 dan sebaliknya apabila $\mathrm{B} / \mathrm{C}<1$ berarti pola tanam tidak menguntungkan.

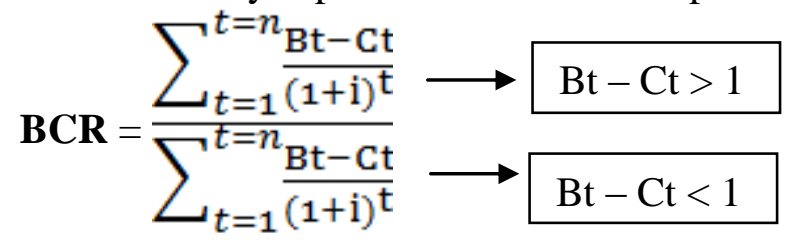

Keterangan:

$\mathrm{BCR}=$ perbandingan antara pendapatan dan pengeluaran

3. Internal Rate of Return (IRR)

Penerapan pola tanam agroforestri dikatakan menguntungkan apabila IRR > i.

IRR $=i_{1}+\frac{N P V_{1}}{N P V_{2}-N P V_{1}} \times i_{2}-i_{1}$

Keterangan:

IRR = suku bunga maksimum yang dapat oleh suatu proyek (\%)

$\mathrm{NPV}_{1}=$ nilai NPV yang positif pada tingkat suku bunga tertentu (Rp)

$\mathrm{NPV}_{2}=$ nilai NPV yang negatif pada tingkat suku bunga tertentu (Rp)

$\mathrm{i}_{1} \quad=$ tingkat bunga pertama dimana diperoleh NPV positif $(\%)$

$\mathrm{i}_{2} \quad=$ tingkat bunga kedua dimana diperoleh NPV negatif $(\%)$ 


\section{HASIL DAN PEMBAHASAN}

Pola tanam agroforestri yang diterapkan petani di Desa Pesawaran Indah tersebar pada 3 fisiografi berdasarkan ketinggian tempat/elevasi lahan. Menurut Indra, dkk (2006) klasifikasi ketinggian tempat dari permukaan laut tipe hutan terdiri dari dataran rendah (0-300 mdpl), perbukitan (300-800 mdpl) dan pegunungan (800-1500 mdpl) sehingga lokasi penelitian di Desa Pesawaran Indah terbagi atas beberapa fisiografi yaitu bawah, tengah dan atas. Setiap fisiografi masing-masing memiliki tiga pola tanam yang berbeda-beda. Pola tanam I, II dan III berada pada fisiografi atas, pola tanam IV, V dan VI berada pada fisiografi tengah dan pola VII, VIII dan IX berada pada fisiografi bawah seperti yang disajikan pada Gambar 1.

Ketiga fisiografi tersebut memiliki tanaman dominan yang berbeda-beda. Jenis tanaman yang dominan antara lain Kakao, Kopi, Kelapa, Medang, Pisang, Bayur, Waru, Cempaka, Pala dan Durian. Tanaman dominan ini merupakan penyusun tanaman utama dari masing-masing pola. Dilihat dari jenis tanaman dominan tersebut, ada 9 pola tanam yang diterapkan petani seperti disajikan pada Tabel 1 .

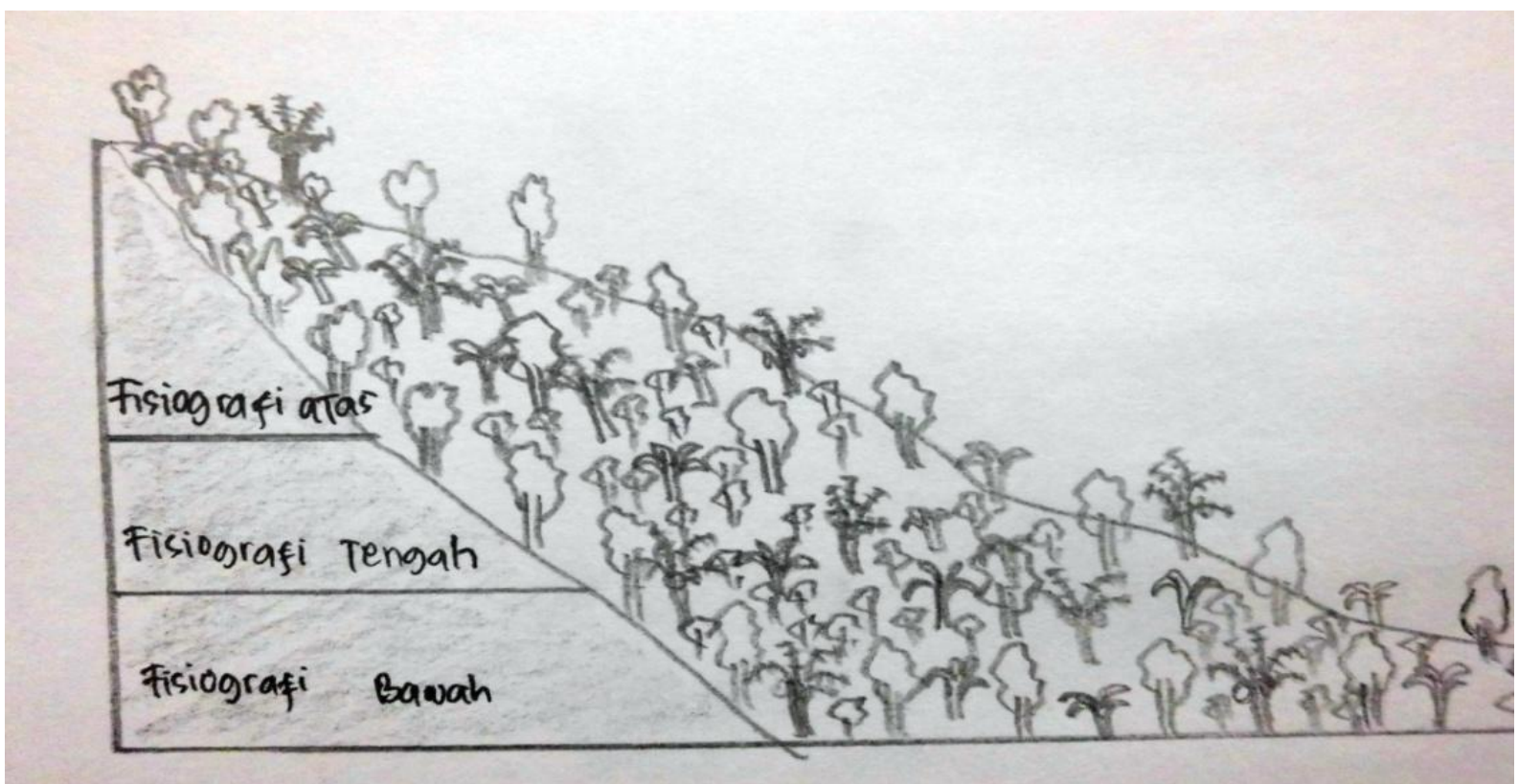

Gambar 1. Sketsa lokasi agroforestri berdasarkan ketinggian tempat.

Tabel 1. Pola tanam yang diterapkan petani di Desa Pesawaran Indah berdasarkan jenis tanaman utama dan fisiografi.

\begin{tabular}{cllc}
\hline $\begin{array}{c}\text { Pola } \\
\text { Tanam }\end{array}$ & \multicolumn{1}{c}{$\begin{array}{c}\text { Jenis Tanaman } \\
\text { Utama }\end{array}$} & \multicolumn{1}{c}{ Jenis Tanaman Pengisi } & $\begin{array}{c}\text { Zona } \\
\text { Fisiografi }\end{array}$ \\
\hline I & $\begin{array}{l}\text { Kakao, Kopi, } \\
\text { Pala } \\
\text { Kakao, Kelapa, } \\
\text { BI }\end{array}$ & $\begin{array}{l}\text { Pisang, Kelapa, Cengkeh, Mindi, Waru, Nangka, Jati, } \\
\text { Cempaka, Medang } \\
\text { Pisang, Waru, Alpukat, Kedondong, Julang-jaling, Durian }\end{array}$ & Atas \\
III & $\begin{array}{l}\text { Kakao, Pisang, } \\
\text { Medang }\end{array}$ & Kelapa, Pala, Mahoni, Nangka & Atas \\
IV & $\begin{array}{l}\text { Kakao, Pisang, } \\
\text { Waru }\end{array}$ & $\begin{array}{l}\text { Cempaka, Kelapa, Durian, Bayur, Mangga, Jengkol, Petai, } \\
\text { Cengkeh, Nangka, Pala, Alpukat }\end{array}$ & Tengah
\end{tabular}


Tabel 1 (lanjutan)

\begin{tabular}{|c|c|c|c|}
\hline $\mathrm{V}$ & $\begin{array}{l}\text { Kakao, Durian, } \\
\text { Kelapa }\end{array}$ & $\begin{array}{l}\text { Pisang, Petai, Bayur, Duku, Mangga, Cengkeh, Cempaka, } \\
\text { Jeruk, Manggis }\end{array}$ & Tengah \\
\hline VI & $\begin{array}{l}\text { Kakao, Kelapa, } \\
\text { Pisang }\end{array}$ & $\begin{array}{l}\text { Pala, Cengkeh, Alpukat, Mangga, Rambutan, Sawo, } \\
\text { Medang, Cempaka }\end{array}$ & Tengah \\
\hline VII & $\begin{array}{l}\text { Kakao, Cempaka, } \\
\text { Kelapa }\end{array}$ & $\begin{array}{l}\text { Cengkeh, Pala dan Pisang, Bayur, Durian, Sengon, Nangka, } \\
\text { Petai, Medang, Akasia }\end{array}$ & Bawah \\
\hline VIII & $\begin{array}{l}\text { Kakao, Kelapa, } \\
\text { Pala }\end{array}$ & $\begin{array}{l}\text { Jati, Bayur dan Pisang, Duku, Jati, Waru, Dadap, Sengon, } \\
\text { Nangka, Cempaka, Durian, Bayur, Pulai, Salak }\end{array}$ & Bawah \\
\hline IX & $\begin{array}{l}\text { Kakao, Pisang, } \\
\text { Cempaka }\end{array}$ & Medang, Karet, Jati, Pala, Sawo, Bayur, Waru, Mangga & Bawah \\
\hline
\end{tabular}

Setiap pola terdiri dari tiga jenis tanaman utama dan beberapa jenis tanaman pengisi. Tanaman utama adalah tanaman yang do-minan dalam suatu pola sedangkan tanaman pengisi tidak mendominasi. Tanaman utama mendominasi sekitar $50 \%-70 \%$ pada pola tanam yang diusahakan petani. Salah satu tanaman utama yang banyak ditanam petani di Desa Pesawaran adalah Kakao. Sekitar 90\% petani menanam Kakao di lahan agroforestri yang diusahakan. Pengusahaan lahan agroforestri dalam penelitian ini diasumsikan selama 20 tahun disesuaikan dengan umur ekonomis Kakao sebagai tanaman utama yang paling dominan (Siregar dkk, 2007).

Pola tanam I memiliki tanaman utama Kakao, Kopi danPala. Tanaman pengisi adalah Pisang, Kelapa, Cengkeh, Mindi, Waru, Nangka, Jati, Cempaka dan Medang. Namun tidak semua jenis tanaman ini memberikan manfaat ekonomis bagi petani, karena beberapa diantaranya seperti Mindi, Waru, Nangka, Jati, Cempaka dan Medang merupakan tanaman subsisten. Tanaman subsisten adalah tanaman yang tidak menghasilkan nilai uang (tidak dijual) sedangkan tanaman komersil merupakan tanaman yang menghasilkan nilai uang (dijual) oleh petani. Petani memilih Kakao menjadi salah satu tanaman utama untuk ditanam karena Kakao dapat dipanen secara rutin setiap tahun serta memiliki masa produksi lebih cepat dibanding tanaman lainnya (khususnya kayu-kayuan). Kakao mulai berproduksi pada umur 3 tahun dan proses pemanenannya dapat dilakukan 15 hari sekali atau 2 minggu sekali.

Pola tanam I yang berada pada fisiografi atas dengan ketinggian di atas $800 \mathrm{mdpl}$ sangat mendukung petani untuk menanam Kopi sebagai tanaman utama. Tanaman Kopi tidak ditemukan pada pola-pola lainnya, hal ini dikarenakan tanaman Kopi akan tumbuh berkembang baik pada ketinggian 750 mdpl (Yardha dan Karim, A., 2000). Umumnya petani menanam Kopi Robusta yang berproduksi pada umur 4 tahun dengan musim panen 4 bulan yaitu pada bulan Juni-September serta pemanenan hampir sama dengan Kakao yaitu 2 minggu sekali. Petani menggunakan jarak tanam $3 \mathrm{~m} \times 3 \mathrm{~m}$ dan ada juga yang menggunakan jarak $3 \mathrm{~m} \times 4 \mathrm{~m}$ baik untuk tanaman Kopi maupun Kakao. Pada pola ini tidak ada satupun jenis tanaman penghasil kayu-kayuan yang dijadikan sebagai tanaman utama karena kayukayuan membutuhkan waktu masa tebang/umur produksi yang cukup lama untuk dapat dipanen. Sementara hasil pengusahaan agroforestri ini merupakan sumber penghasilan utama bagi petani untuk memenuhi kebutuhan sehari-hari.

Pengusahaan pola tanam agroforestri membutuhkan biaya produksi, baik itu untuk biaya bibit, biaya pupuk, biaya peralatan (alat tani) maupun biaya untuk tenaga kerja. Penggunaan masing-masing komponen biaya tersebut mempengaruhi manfaat secara ekonomis yang diperoleh petani, tergantung dari besar kecilnya komponen biaya yang digunakan. Pada pola ini petani mengeluarkan biaya untuk pembelian bibit Pala dan Kakao, sedangkan untuk jenis tanaman lainnya petani menyemaikan bibit sendiri. Petani juga mengeluarkan biaya untuk 
pupuk maupun pestisida seperti urea, KCL, TSP, roundup dan pastak. Selain pupuk buatan petani juga menggunakan pupuk kandang dalam pengusahaan pola tanam agroforestri. Namun petani tidak mengeluarkan biaya untuk pupuk kandang karena sebagian besar petani memelihara ternak sehingga kotorannya dapat dimanfaatkan sebagai pupuk kandang. Petani menggunakan tenaga kerja keluarga dan ada juga yang menggunakan tenaga kerja luar keluarga dalam pengusahaan agroforestri. Penambahan tenaga kerja luar keluarga digunakan pada saat-saat tertentu khususnya pada saat pasca panen.

Penerimaan petani yang dimasukkan dalam perhitungan analisis bersumber dari hasil panen tanaman komersil. Berdasarkan hasil perhitungan diperoleh nilai NPV sebesar Rp 35.851.937,83,-. Nilai NPV tersebut menunjukkan manfaat secara ekonomis yang diterima pada pengusahaan pola tanam agroforestri. Nilai BCR pola I sebesar 4,18 yang berarti bahwa dari setiap rupiah biaya yang dikeluarkan menghasilkan keuntungan sebesar Rp 4,18,-. Nilai IRR sebesar $47 \%$ yang berarti dari setiap rupiah yang diinvestasikan selama umur pengusahaan pola tanam agroforestri akan memberikan pengembalian modal $47 \%$ maka secara finansial pola tanam I layak (menguntungkan). Hal ini di dukung dengan hasil penelitian Trisnawati, dkk (2004) tentang kelayakan usaha tani pola tumpangsari tanaman Kopi dengan nilai NPV sebesar Rp 33.599.884,-, BCR sebesar 1,58 dan IRR sebesar 13\%.

Pola tanam ini berada pada fisiografis atas dengan tanaman utama adalah Kakao, Kelapa dan Bayur sedangkan tanaman pengisi adalah Pisang, Waru, Alpukat, Kedondong, Julang-jaling dan Durian. Adapun tanaman komersilnya adalah Kakao, Kelapa, Bayur, Pisang dan Waru sedangkan yang lainnya termasuk tanaman subsisten. Pada pola ini terdapat tanaman kayu-kayuan sebagai tanaman utama. Umumnya tanaman penghasil kayu ini dijadikan sebagai tanaman pelindung. Tanaman penghasil kayu ini dipanen ketika petani membutuhkan biaya pada saat-saat tertentu maupun pada saat pembangunan rumah. Kakao pada pola ini mulai berproduksi pada umur 3 tahun dan jarak tanam sedikit lebih jarak dibanding pola sebelumnya yaitu $3 \mathrm{~m} \times 4 \mathrm{~m}$ dan ada juga $4 \mathrm{~m} \times 4 \mathrm{~m}$. Pengelolaan pola tanam sama halnya dengan pola I yaitu menggunakan pupuk dan pestisida. Pupuk dan pestisida yang digunakan adalah urea, pastak dan roundup. Penggunaan pupuk/pestisida pada pola ini jauh lebih sedikit (1:3) dibandingkan dengan pola I. Untuk tenaga kerja petani pada pola ini menggunakan tenaga kerja keluarga dan tenaga kerja luar keluarga pada saat-saat tertentu. Berdasarkan hasil perhitungan diperoleh nilai NPV sebesar Rp 22.445.918,85,- yang menunjukkan keuntungan yang diterima pada pengusahaan pola tanam. Nilai BCR pola II sebesar 3,91 yang berarti bahwa setiap rupiah biaya yang dikeluarkan menghasilkan keuntungan sebesar Rp 3,91,-. Nilai IRR 65\% yang berarti bahwa dari setiap rupiah yang diinvestasikan selama umur pengusahaan pola tanam agroforestri akan memberikan pengembalian modal $65 \%$ sehingga secara finansial pola tanam II layak/menguntungkan.

Kakao, Pisang dan Medang menjadi tanaman utama pada pola ini sedangkan tanaman pengisi adalah Kelapa, Pala, Mahoni dan Nangka. Tanaman subsisten pada pola ini adalah Nangka dan Mahoni sedangkan yang lainnya merupakan tanaman komersil. Pada pola ini $60 \%$ petani memilih Pisang sebagai tanaman utama karena Pisang merupakan tanaman yang cepat berproduksi. Selain pemeliharaannya yang mudah, proses pemanenannya juga tidak sulit. Pisang mulai berproduksi pada tahun ke-2 sedangkan Kakao mulai berproduksi pada umur 3 tahun dengan jarak tanam tidak jauh berbeda dengan pola I yaitu $3 \mathrm{~m} \times 4 \mathrm{~m}$. Berdasarkan hasil perhitungan diperoleh nilai NPV sebesar Rp 39.047.832,32,- yang menunjukkan manfaat secara ekomis yang diterima pada pengusahaan agroforestri. Nilai BCR sebesar 4,98 yang berarti bahwa setiap rupiah biaya yang dikeluarkan menghasilkan keuntungan sebesar Rp 4,98,-. Nilai IRR $85 \%$ yang berarti bahwa dari setiap rupiah yang diinvestasikan selama umur pengusahaan pola tanam agroforestri akan memberikan pengembalian modal $85 \%$. Berdasarkan hasil analisis maka secara finansial pola tanam II dapat dikatakan menguntungkan. Pengelolaan agroforestri petani menemukan beberapa 
masalah seperti adanya penyakit berupa bintik-bintik hitam yang banyak ditemukan pada buah Kakao yang masih kecil yang dapat menghambat perkembangan buah Kakao. Selain itu dalam proses pemasaran juga petani masih kurang efisien. Petani tidak menjual hasil panen ke pasar melainkan pengumpul yang datang ke rumah-rumah sehingga kesempatan petani untuk mempertahankan harga semakin berkurang.

Pola IV berada pada fisiografi tengah dengan tanaman utama adalah Kakao, Pisang dan Waru sedangkan tanaman pengisi adalah Cempaka, Kelapa, Durian, Bayur, Mangga, Jengkol, Petai, Cengkeh, Nangka, Pala dan Alpukat. Tanaman komersil adalah Kakao, Pisang, Waru, Cempaka, Kelapa dan Durian. Pada pola ini banyak tanaman pengisi yang belum memberikan manfaat secara ekonomis karena beberapa diantaranya seperti Cengkeh, Durian, Kelapa, Nangka dan Pala masih belum menghasilkan buah. Petani menggunakan jarak tanam $3 \mathrm{~m} \times 3 \mathrm{~m}$ untuk Kakao. Pada pola ini petani meng-gunakan pupuk kandang dan pupuk kimia tetapi penggunaan pupuk kandang lebih diutamakan. Berdasarkan hasil perhitungan diperoleh nilai NPV sebesar Rp 70.403.565,19,-. Nilai NPV tersebut menunjukkan keuntungan yang diterima selama pengusahaan agroforestri. Nilai BCR pola IV sebesar 7,31 yang berarti bahwa setiap rupiah biaya yang dikeluarkan menghasilkan keuntungan sebesar Rp 7,31,-Nilai IRR $89 \%$ yang berarti bahwa dari setiap rupiah yang diinvestasikan selama umur pengusahaan pola tanam agroforestri akan memberikan pengembalian modal $89 \%$.

Pola V sama dengan pola IV berada pada fisiografis tengah dengan tanaman Kakao, Durian dan Kelapa sebagai tanaman utama dan tanaman pengisi yang termasuk tanaman komersil adalah Pisang, Petai, Bayur sedangkan Duku, Mangga, Cengkeh, Cempaka, Jeruk dan Manggis merupakan tanaman subsisten. Selain sebagai penghasil buah yang khusus untuk dikonsumsi sendiri tanaman ini juga sengaja dipelihara sebagai tanaman pelindung. Petani pada pola ini menggunakan jarak tanam $3 \mathrm{~m} \times 4 \mathrm{~m}$ untuk tanaman Kakao dan pemanenan dilakukan 15 hari atau 2 minggu sekali. Petani menyemaikan bibit sendiri, sama sekali tidak mengeluarkan biaya untuk bibit. Sama halnya dengan pola-pola sebelumnya petani pada pola ini menggunakan tenaga kerja keluarga dan luar keluarga juga menggunakan pupuk/pestisida namun dalam jumlah yang berbeda tergantung bagaimana perawatan masingmasing petani. Hasil perhitungan diperoleh nilai NPV sebesar Rp 39.499.108,41,- yang menunjukkan keuntungan yang diterima dalam pengusahaan agroforestri. Nilai BCR pada pola ini sebesar 6,26 yang berarti bahwa setiap rupiah biaya dikeluarkan menghasilkan keuntungan sebesar Rp 6,26,-. Nilai IRR 78\% yang berarti bahwa dari setiap rupiah yang diinvestasikan selama umur pengusahaan pola tanam agroforestri akan memberikan pengembalian modal $78 \%$.

Kakao, Kelapa dan Pisang merupakan tanaman utama dan sekaligus tanaman komersil dan tanaman pengisi yang komersil adalah Pala dan Cengkeh. Tanaman subsisten adalah Alpukat, Mangga, Rambutan, Sawo, Medang dan Cempaka. Petani memilih Kelapa menjadi salah satu tanaman utama pada pola ini karena Kelapa dapat menjadi sumber pendapatan mingguan bagi petani selain itu Kelapa juga tidak butuh pemeliharaan. Pisang dipilih karena cepat berproduksi dan setiap bulannya dapat dipanen. Pada pola ini tidak terdapat tanaman kayu-kayuan sebagai tanaman komersil. Sebagai penjaga sistem ekologi lingkungan dan penaung bagi tanaman lainnya misalnya Kakao karena tanaman ini butuh lindungan dari tiupan angin dan sinar matahari (Dahlan, 2012). Hal ini didukung oleh hasil penelitian Obiri, dkk (2007) yang menjelaskan bahwa Kakao yang berada di bawah naungan memiliki umur ekonomis yang lebih lama dibanding yang tidak mendapat naungan. Jarak tanam hampir sama dengan jarak tanam pada pola sebelumnya yaitu $3 \mathrm{~m} \times 4 \mathrm{~m}$ untuk tanaman Kakao dengan waktu pemanenan 15 hari sekali atau 2 minggu sekali. Tidak jauh berbeda dengan pola-pola sebelumnya petani pada pola ini menggunakan pupuk dan pestisida dan tenaga kerja keluarga maupun tenaga kerja luar keluarga. Pada pola ini perlakuan budidayanya lebih baik dibanding dengan pola-pola lainnya baik dari segi pemeliharaan maupun pemupukan. 
Berdasarkan perhitungan diperoleh nilai NPV sebesar Rp 71.392.802,34,- yang menunjukkan keuntungan yang diterima dalam pengusahaan agroforestri. Nilai BCR sebesar 7,39 yang berarti bahwa setiap rupiah biaya yang dikeluarkan menghasilkan keuntungan sebesar Rp 7,39,-. Nilai IRR 96\% yang berarti dari setiap rupiah yang diinvestasikan selama umur pengusahaan pola tanam agroforestri akan memberikan pengembalian modal $96 \%$.

Tanaman utama pada pola VII adalah Kakao, Cempaka dan Kelapa sedangkan tanaman pengisi adalah Cengkeh, Pala dan Pisang yang merupakan tanaman komersil sedangkan Bayur, Durian, Sengon, Nangka, Petai, Medang dan Akasia termasuk tanaman subsisten. Pada pola ini tanaman subsisten seperti Durian, Nangka dan Petai hanya terdapat 3-4 pohon sehingga $\pm 90 \%$ petani sengaja memeliharanya untuk dikonsumsi sendiri bukan untuk dijual. Untuk jenis tanaman penghasil kayu seperti Akasia dan Sengon masih baru ditanam dan sebagian sengaja tidak ditebang karena dijadikan sebagai tanaman pelindung/penaung. Berdasarkan hasil perhitungan diperoleh nilai NPV sebesar Rp 36.825.124,37,- yang menunjukkan keuntungan yang diterima dalam pengusahaan agroforestri. Nilai BCR sebesar 4,91 yang berarti bahwa setiap rupiah biaya yang dikeluarkan menghasilkan keuntungan sebesar Rp 4,91,-. Nilai IRR 55\% artinya dari setiap rupiah yang diinvestasikan selama umur pengusahaan pola tanam agroforestri memberikan pengembalian modal $55 \%$.

Pola tanam VIII berada pada fisiografis bawah dengan tanaman utama adalah Kakao, Kelapa dan Pala. Jati, Bayur dan Pisang merupakan tanaman pengisi yang termasuk komersil sedangkan tanaman pengisi lainnya yang menjadi tanaman subsisten yaitu: Duku, Jati, Waru, Dadap, Sengon, Nangka, Cempaka, Durian, Bayur, Pulai dan Salak. Jarak tanam Kakao pada pola ini $3 \mathrm{~m} \times 3 \mathrm{~m}$. Petani beranggapan bahwa tanaman kayu dapat dijadikan sebagai tabungan untuk masa depan sehingga perlahan petani sudah mulai menanamnya di lahan agroforestri yang diusahakan. Hasil perhitungan diperoleh nilai NPV sebesar Rp 48.336.243,72,- yang menunjukkan keuntungan yang diterima dalam pengusahaan agroforestri. Nilai BCR sebesar 5,64 yang berarti bahwa setiap rupiah biaya yang dikeluarkan menghasilkan keuntungan sebesar Rp 5,64,-. Nilai IRR 64\% yang berarti bahwa dari setiap rupiah yang diinvestasikan selama umur pengusahaan pola tanam agroforestri memberikan pengembalian modal $64 \%$.

Tanaman utama pada pola ini merupakan tanama komersil yang terdiri dari Kakao, Pisang, dan Cempaka sedangkan tanaman pengisi adalah Medang, Karet, Jati, Pala, Sawo, Bayur, Waru dan Mangga. Namun diantaranya yang termasuk tanaman komersil adalah Durian, Kelapa dan Sengon sedangkan yang lainnya merupakan tanaman subsisten. Penjualan hasil kayu seperti Cempaka dan Sengon dilakukan dengan sistem borongan, hal ini berlaku untuk semua jenis kayu pada pola IX. Jarak tanam Kakao pada pola ini $3 \mathrm{~m} \times 4 \mathrm{~m}$ dengan umur mulai berproduksi sama halnya dengan pola-pola sebelumnya. Pola ini layak berdasarkan finansial sesuai dengan hasil perhitungan yaitu nilai NPV sebesar Rp 52.038.191,10,- yang menunjukkan keuntungan yang diterima pada pengusahaan agroforestri. Nilai BCR sebesar 5,52 yang berarti bahwa setiap rupiah biaya yang dikeluarkan menghasilkan keuntungan sebesar Rp 5,52,-. Nilai IRR 91\% yang berarti bahwa dari setiap rupiah yang diinvestasikan selama umur pengusahaan pola tanam agroforestri akan memberikan pengembalian modal $91 \%$.

Sesuai dengan kriteria finansial maka 9 (sembilan) pola tanam yang diterapkan di Desa Pesawaran Indah dikatakan layak secara finansial. Pola tanam VI (Kakao + Kelapa + Pisang) dianggap lebih layak/menguntungkan karena memperoleh nilai yang lebih besar dibanding dengan pola lainnya yaitu nilai NPV sebesar Rp 71.392.802,34,-, BCR sebesar 7,39 dan IRR sebesar 96\%. Hal ini didukung oleh penelitian Kusumedi (2010) yang menghasilkan nilai NPV sebesar Rp 112.039.098,-, nilai BCR sebesar 2,32 dan nilai IRR 35\% lebih besar dari tingkat suku bunga yang digunakan yaitu 9,3\%. 


\section{SIMPULAN}

Terdapat 9 (sembilan) pola tanam agroforestri yang diterapkan petani di Desa Pesawaran Indah. Semua pola tanam tersebut layak secara finansial. Pola tanam VI dengan tanaman utama Kakao, Kelapa dan Pisang memiliki kelayakan yang lebih tinggi dibanding pola lainnya dengan nilai NPV sebesar Rp 71.392.802,34,-, nilai BCR sebesar 7,39 dan IRR sebesar $96 \%$.

\section{DAFTAR PUSTAKA}

Dahlan. 2012. Perawatan tanaman kakao, pohon pelindung tanaman kakao dan panen buah kakao. Diakses 10 November 2012. Jam 10.78. http://www.peradabanbangsa.com/ 2012/04/makalah-perawatan-tanaman-kakao-pohon.html.

Febryano, I. G. 2009. Analisis finansial agroforestri kakao di lahan hutan negara dan lahan milik. Jurnal Perennial. 4(1):41- 47.

Indra, S., Prasetyo, dan Soekmadi. 2006. Penyusunan zonasi Taman Nasional Manupeu Tanadaru, Sumba berdasarkan kerentanan kawasan dan aktivitas masyarakat. Jurnal Media Konservasi. Institut Pertanian Bogor. XI(1):1-16.

Kusumedi, P. dan N. A. Jariyah. 2010. Analisis finansial pengelolaan agroforestri dengan pola aengon kapulaga di Desa Tirip, Kecamatan Wadaslintang, Kabupaten Wonosobo. Jurnal Penelitian Sosial dan Ekonomi Kehutanan. 7(2):93-100.

Muhtarom. 2012. Sistem budidaya intensif terbukti tingkatkan produktivitas. Diakses 26 November 2012. jam 10.12. http://kangtarom. Blogspot.com/2012/06/sistim-budidayaintensif-terbukti.html.

Obiri, B. D., G. A. Bright, M. A. McDonald, L. C. N. Anglaaere, and J. Cobbina. 2007. Financial analysis of shaded cocoa in Ghana. Agroforestry System. 71:139-149.

Siregar, T. H. S., S. Riyadi, dan L. Nuraeni. 2007. Cokelat: Pembudidayaan, Pengolahan, Pemasaran. Buku. Penebar Swadaya. Jakarta.

Suharjito, Widianto, Kurniatun dan Mustofa, A. S. 2003. Bahan ajaran agroforestri 1. aspek sosial ekonomi dan budaya agroforestri. World Agroforestry Centre (ICRAF). Bogor.

Umar. 2000. Riset Sumberdaya Manusia Dalam Organisasi. Buku. Gramedia Pustaka Ilmu. Jakarta.

Yardha dan Karim, A. 2000. Pengembangan kopi arabika di Aceh Tengah: ketersediaan dan kesesuaian lahan. Monograf Series No.1, Kerjasama Fakultas Pertanian Universitas Syiah Kuala Banda Aceh dengan Loka Pengkajian Teknologi Pertanian Banda Aceh. Banda Aceh. 
Vol. I No. I. September 2013 (65-74)

Halaman ini sengaja dikosongkan 